JDHT Journal of Dental Hygiene and Therapy

Volume 1, Nomor 1 Tahun 2020

eISSN : xxxx-Xxxx, DOI: xx.xxxxx/jdht.vxix.xx

\title{
FAKTOR PENYEBAB TINDAKAN PENCABUTAN GIGI PERMANEN DI KLINIK KEMANG CONFI DENTAL CARE PERIODE JANUARI-DESEMBER 2019
}

\author{
Indrayati Fadjeri $^{1}$, Eka Anggreni ${ }^{2}$, Vitri Nurilawaty ${ }^{3}$, Syifa Yulia Lestari ${ }^{4}$, Siti Wahyuni Ardina ${ }^{5}$
} 1,2,3,4,5 Jurusan Keperawatan Gigi, Politeknik Kesehatan Kemenkes Jakarta I, Indonesia

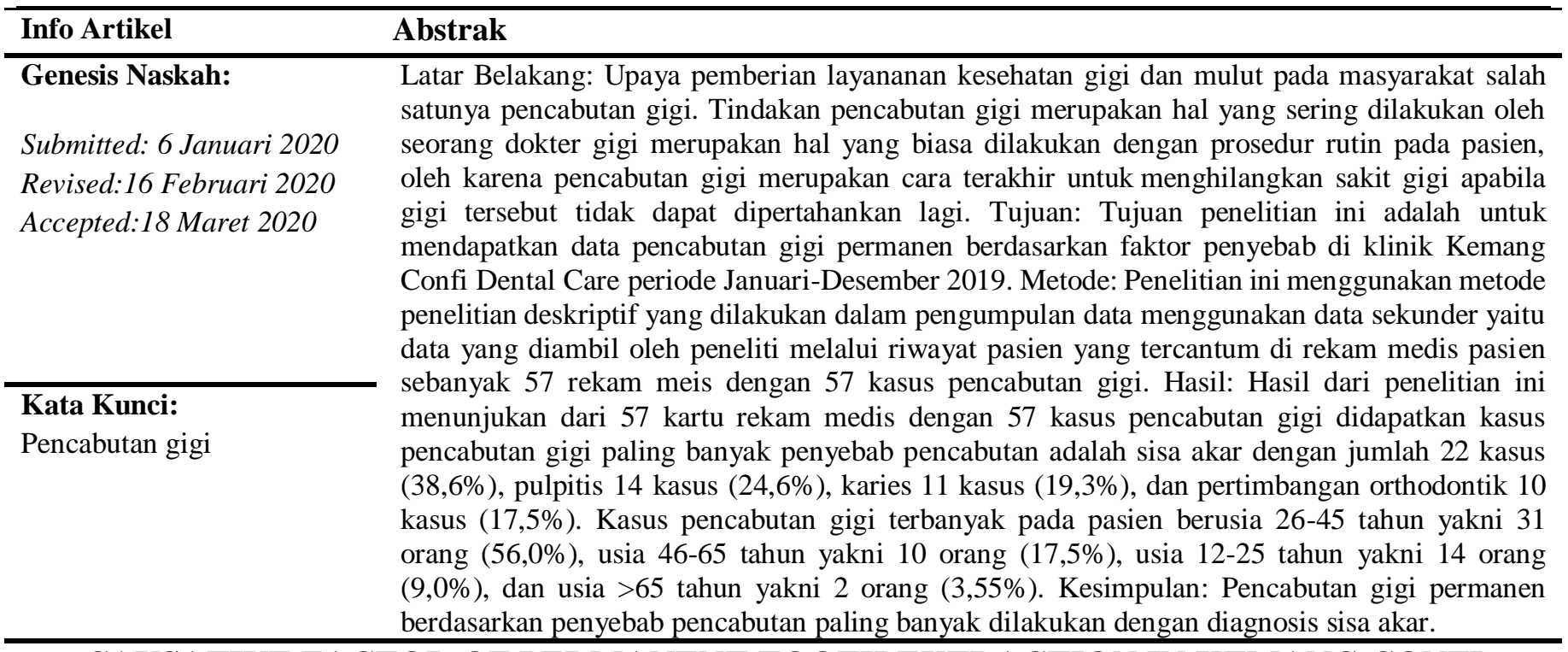

CAUSATIVE FACTOR OF PERMANENT TOOTH EXTRACTION IN KEMANG CONFI DENTAL CARE CLINIC JANUARY-DECEMBER 2019

\section{Keywords:}

Tooth ectraction

\begin{abstract}
Background: The effort to grant dental and oral health to the public is one of the extractions of teeth. Tooth extractions are often done by a dentist thit is commonly done with routine procedures in patients, because tooth extraction is the last way to relieve toothache when it cannot be sustained anymore. Objective: The purpose of this research is to obtain permanent tooth extraction data based on the causal factors at the Kemang Confi Dental Care Clinic in the period of January-December 2019. Method: This study uses a descriptive research method conducted in the collection of data using secondary data that is data collected by researchers through the patient's history listed in the patient's medical record as much as 47 medical records with 57 cases of tooth extraction. Results: The results of this study showed from 47 medical record cards with 57 cases of tooth extractions obtained the most common tooth extraction case caused the revocation was the residual roots with a total of 22 cases (38.6\%), pulpitis 14 cases (24.6\%), caries 11 cases $(19.3 \%)$, and the orthodontic considerations of 10 cases $(17.5 \%)$. The most cases of tooth extraction in patients aged 26-45 years is 31 people (56.0\%), the age of 46-65 which is 10 people (17.5\%), the age of $12-25$ is 14 people $(9.0 \%)$, and the age of $>65$ year that is 2 people (3.55\%). Conclusion: Permanent tooth extraction is based on the most common extraction cause by diagnosis of residual roots.
\end{abstract}

Korespondensi Penulis:

Indrayati Fadjeri

Jl. Wijaya Kusuma No. 47-48 Cilandak, Jakarta Selatan, Indonesia

Email: indra_jkg@yahoo.co.id 


\section{Pendahuluan}

Kesehatan gigi dan mulut seringkali dipandang sebelah mata oleh masyarakat dan menganggap prosedur atau tindakan dalam bidang kedokteran gigi adalah hal yang menakutkan. Berdasarkan data dari Riset Kesehatan Dasar (Riskesdas) persentase penduduk yang mempunyai masalah kesehatan gigi dan mulut menurut Riskesdas tahun 2007 dan 2013 meningkat dari 23,2\% menjadi 25,9\%. Dari penduduk yang mempunyai masalah kesehatan gigi dan mulut, persentase penduduk yang menerima perawatan medis meningkat menjadi 31,1\% pada tahun 2013 (Kementerian Kesehatan RI, 2014).

Kesehatan gigi dan mulut seringkali dipandang sebelah mata oleh masyarakat dan menganggap prosedur atau tindakan dalam bidang kedokteran gigi adalah hal yang menakutkan. Masyarakat umumnya datang ke dokter gigi jika telah terjadi kerusakan gigi yang cukup parah dengan keluhan rasa sakit yang sangat mengganggu. Hal ini terutama disebabkan oleh tingkat pendidikan, ekonomi, sosial dan kesadaran dari masyarakat tentang pemeliharaan kesehatan gigi yang masih rendah (Swastini et al., 2007). Penelitian Warouw (2014) menyatakan bahwa sebanyak $78 \%$ responden yang pergi ke dokter gigi/puskesmas, responden cenderung menunggu sampai gigi sudah sangat rusak sehingga tindakan yang dilakukan adalah mencabut gigi. Apabila ada alternative tindakan lain yang bisa dilakukan sebagian responden memilih untuk tetap dilakukan pencabutan dengan alasan tidak ingin sakit gigi lagi (Warouw et al., 2014).

Upaya pemberian pelayananan kesehatan gigi dan mulut pada masyarakat umumnya berupa pencabutan gigi. Tindakan pencabutan gigi merupakan hal yang sering dilakukan oleh seorang dokter gigi pada praktik sehari-hari. Tindakan ini merupakan hal yang biasa dilakukan dengan prosedur rutin pada pasien, oleh karena pencabutan gigi merupakan cara termudah untuk menghilangkan sakit gigi apabila gigi tersebut tidak dapat dipertahankan lagi (Inka et al., 2014).

Pencabutan gigi paling banyak dilakukan karena karies, penyakit periodontal, supernumery

(C) Jurusan Keperawatan Gigi Poltekkes Kemenkes Jakarta I J1. Wijaya Kusuma No. 47-48 Cilandak Jakarta Selatan, Indonesia email: jdht@poltekkesjakarta1.ac.id teeth, gigi impaksi, gigi yang sudah tidak dapat dilakukan perawatan endodontik, dan gigi yang terlibat kista dan tumor dan gigi yang terlibat fraktur rahang. Pencabutan gigi terkadang tidak bisa dilakukan karena beberapa faktor, seperti kelainan sistmatik, contohnya diabetes mellitus, hipertensi, leukemia yang tidak terkontrol, kehamilan, kelainan perdarahan dan kelainan lokal, misalnya perikoronitis akut, oedem berat, abses dento alveolar akut dan sebagainya (Moore, 2011).

Indeks DMF-T menggambarkan tingkat keparahan kerusakan gigi. Indeks DMF-T merupakan penjumlahan dari Indeks D-T, M-T dan F-T. indeks DMF-T ini meningkat seiring dengan bertambahnya umur. Prevalensi nasional Indeks DMF-T adalah 4,6 sebanyak 15 provinsi memiliki prevalensi diatas prevalensi nasional. Indeks DMF-T lebih tinggi pada perempuan $(5,0)$ dibanding laki-laki $(4,1)$ (Riskesdas, 2013).

Berdasarkan latar belakang diatas maka rumusan masalah adalah "Bagaimana faktor penyebab tindakan pencabutan gigi permanen di klinik Kemang Confi Dental Care periode JanuariDesember 2019?"

\section{Metode Penelitian}

Desain penelitian yang digunakan adalah desain deskriptif bertujuan untuk melihat faktor penyebab tindakan pencabutan gigi permanen di klinik Kemang Confi Dental Care periode JanuariDesember 2019. Sampel penelitian menggunakan purposive sampling yang dianggap mewakili seluruh subjek penelitian yang memenuhi kriteria sebanyak 57 responden. Metode pengumpulan data menggunakan data sekunder yaitu data yang diambil oleh peneliti melalui riwayat pasien yang tercantum di rekam medis pasien dan hasil yang disajikan dalam bentuk tabel.

\section{Hasil}

Hasil penelitian menunjukan bahwa dari 57 kasus pencabutan gigi paling banyak penyebab pencabutan adalah sisa akar dengan jumlah 22 kasus $(38,6 \%)$, pada urutan kedua pulpitis dengan jumlah 14 kasus $(24,6 \%)$, pada urutan ketiga karies dengan jumlah 11 kasus (19,3\%), dan urutan terakhir 
pertimbangan orthodontik dengan jumlah 10 kasus $(17,5 \%)$. Lebih jelasnya terdapat pada tabel berikut :

Tabel 1. Distribusi pencabutan gigi permanen menurut faktor penyebab di klinik Kemang Confi Dental Care Periode Januari-Desember 2019

\begin{tabular}{lcc}
\hline $\begin{array}{l}\text { Faktor Penyebab } \\
\text { Pencabutan Gigi }\end{array}$ & Jumlah & $\begin{array}{c}\text { Persentase } \\
(\%)\end{array}$ \\
\hline Karies & 11 & 19,3 \\
Pulpitis & 14 & 24,6 \\
Sisa akar & 22 & 38,6 \\
Pertimbangan Orthodontik & 10 & 17,5 \\
\hline Total & 57 & 100 \\
\hline
\end{tabular}

Tabel 2. Distribusi pencabutan gigi permanen menurut usia di klinik Kemang Confi Dental Care Periode Januari-Desember 2019

\begin{tabular}{lcc}
\hline Kriteria Usia & Jumlah & Persentase (\%) \\
\hline $12-25$ tahun & 14 & 9,0 \\
$26-45$ tahun & 31 & 56,0 \\
$46-65$ tahun & 10 & 17,5 \\
$>65$ tahun & 2 & 3,5 \\
\hline Total & 57 & 100 \\
\hline
\end{tabular}

Tabel 2 menujukan bahwa dari 57 responden yang diteliti, kasus pencabutan gigi terbanyak pada pasien berusia 26-45 tahun yakni sebanyak 31 pasien $(56,0 \%)$, pada kategori usia 46-65 tahun yakni 10 pasien $(17,5 \%)$, pada kategori usia $12-25$ tahun yakni 14 pasien $(9,0 \%)$, dan pada kategori $>65$ tahun yakni 2 pasien $(3,5 \%)$.

\section{Pembahasan}

Berdasarkan hasil penelitian faktor penyebab pencabutan gigi tetap di klinik Kemang Confi Dental Care periode Januari-Desember 2019 di dapatkan bahwa sisa akar adalah salah satu penyebab/kasus tertingi di klinik Kemang Confi Dental Care dengan 22 kasus dari 57 kasus yang mencapai $(38,6 \%)$. Hal ini sependapat dengan hasil penelitian Masagus et al (2014) mengatakan bahwa penyebab pencabutan gigi tertinggi yaitu gangren radiks dengan kasus sebanyak $18(41,2 \%)$. Hasil ini berbeda dengan hasil penelitian dari Zakia et al (2016) yang meneliti tentang distribusi frekuensi faktor penyebab ekstraksi gigi (C) Jurusan Keperawatan Gigi Poltekkes Kemenkes Jakarta I Jl. Wijaya Kusuma No. 47-48 Cilandak Jakarta Selatan, Indonesia email: jdht@poltekkesjakarta1.ac.id pasien di Rumah Sakit Umum dr. Zainoel Abidin Banda Aceh Periode Mei-Juli 2016. Dengan hasil penelitian kasus terbanyak dari ekstraksi gigi adalah gigi karies yaitu sebanyak $79(37,1 \%)$ kasus (Zakia et al., 2013).

Perbedaan hasil yang didapatkan peneliti bisa disebabkan oleh beberapa faktor. faktor pertama ialah perbedaan tempat penelitian seperti yang diungkapkan oleh Al-Sharafat bahwa perbedaan budaya mempengaruhi hasil penelitian juga dengan jumlah sampel yang berbeda mempengaruhi hasil persentasi. Faktor lainnya bisa diasumsikan disebabkan pasien menunda atau tidak ingin untuk melakukan perawatan, mereka lebih memilih minum obat untuk menghilangkan rasa sakit sehingga proses karies itu terus berlanjut menjadi gangrene radiks (Sharafat dan Nengrish, 2008).

Karies yang meluas dan tidak dapat dirawat mengakibatkan hilangnya mahkota gigi sepenuhnya dan menyisikan akar (sisa akar) atau disebut juga sebagai gangrene radiks. Gangrene radiks biasanya memiliki lesi periapikal yang bersifat kronis dengan tidak ada gejala ataupun eksaserbasi akut akibat infeksi sekunder yang mengakibatkan rasa sakit. Beberapa lesi periapikal yang sering terjadi diantaranya adalah granuloma periapikal dan kista radikula (Budi, 2010).

Karies yang meluas dan tidak dapat dirawat mengakibatkan hilangnya mahkota gigi sepenuhnya dan menyisikan akar (sisa akar) atau disebut juga sebagai gangrene radiks. Gangrene radiks biasanya memiliki lesi periapikal yang bersifat kronis dengan tidak ada gejala ataupun eksaserbasi akut akibat infeksi sekunder yang mengakibatkan rasa sakit. Beberapa lesi periapikal yang sering terjadi diantaranya adalah granuloma periapikal dan kista radikula (Budi, 2010).

Minuman berakohol selain dampak berakibat buruk bagi tubuh seperti pancreas, saluran pencernaan, otot, darah, jantung kelenjar endokrin, dan bagian tubuh lainnya termasuk dalam mulut. Salah satu efek secara fisik dari minuman alcohol ialah membuat penurunan ph saliva sehingga membuat suasana kering pada permukaan mukosa rongga mulut (xerostomia). Kondisi ini membuat 
permukaan gigi geligi dalam mulut rentan terhadap terjadinya karies oleh karena jumlah saliva yang berkurang, saliva memiliki kemampuan untuk mempertahankan pH-nya agar tetap konstan. Atau dikenal dengan efek buffer saliva. Di samping itu cairan saliva dapat berfungsi sebagai self clensing bagi permukaan gigi geligi dan mulut. Dengan demikian berkurangnya jumlah saliva dalam mulut akan meningkatkan risiko gigi geligi terhadap karies (Christian, et al., 2015).

Hasil penelitian tentang faktor penyebab tindakan pencabutan gigi permanen di klinik Kemang Confi Dental Care periode JanuariDesember 2019 berdasarkan usia menunjukan bahwa kategori usia 26-45 tahun dengan jumlah $31(56,0 \%)$ jumlah ini dikarenakan banyak pasien dengan usia berikut melakukan pemasangan orthodontik yang mengharuskan untuk gigi dicabut. Hasil ini berbeda dengan hasil penelitian dari penelitian Masagus et al (2014) dengan hasil terbanyak yaitu kategori usia 65 tahun ke atas yakni sebanyak 9 orang $(28,2)$. Perbedaan hasil yang didapatkan peniliti bisa disebabkan oleh beberapa faktor. Faktor utama adalah adanya perbedaan tempat penelitian dengan perbedaan budaya mempengaruhi hasil penelitian. Perilaku masyarakat pedesaan dan perkotaan terhadap penyakit gigi dan mulut berbeda. Ketika masyarakat di desa mengalami masalah gigi dan mulut, mereka masih menggunakan cara tradisional sesuai dengan pengetahuan dan pengalaman sendiri, atau bantuan orang lain yang bukan berprofesi sebagai dokter gigi, sebaliknya masyarakat perkotaan selalu berkonsultasi dengan dokter gigi ketika mengalami gangguan pada gigi dan mulut, karena pengetahuan mereka tentang kesehatan gigi dan mulut sudah lebih luas. Dan faktor lainnya yaitu dengan perbedaan jumlah responden penelitian.

\section{Kesimpulan}

Berdasarkan hasil penelitian mengenai gambaran pencabutan gigi permanen di klinik Kemang Confi Dental Care periode JanuariDesember 2019 maka didapatkan kesimpulan sebagai berikut:

1. Didapatkan distribusi pencabutan gigi permanen berdasarkan penyebab pencabutan paling banyak

(C) Jurusan Keperawatan Gigi Poltekkes Kemenkes Jakarta I Jl. Wijaya Kusuma No. 47-48 Cilandak Jakarta Selatan, Indonesia email:jdht@poltekkesjakarta1.ac.id dilakukan dengan diagnosis sisa akar sebanyak 22 kasus $(38,6 \%)$.

2. Didapatkan gambaran distribusi pencabutan gigi permanen berdasarkan usia paling banyak ditemukan pada usia 26-45 tahun sebanyak 31 orang $(56,0 \%)$.

\section{Saran}

1. Bagi pasien untuk meningkatkan kesadaran tentang kesehatan gigi dan mulut, serta rutin melakukan kontol ke klinik gigi setiap 6 bulan sekali. Agar jika terjadi lubang gigi dapat ditangani sejak dini.

2. Bagi pihak klinik agar dapat meningkatkan pelayanan kesehatan gigi dan mulut, serta edukasi kepada pasien sehingga pasien lebih tertarik untuk terus melakukan check up kesehatan gigi dan mulut di klinik Kemang Confi Dental Care.

\section{Daftar Pustaka}

Amin MA, Juniati D (2017). Klasifikasi kelompok umur manusia berdasarkan analisisdimensi fractal box counting dari citra wajah dengan deteksi tepi Canny. JurnalIlmiah Matematika, 2(6): 33-42.

Inka JF, Mariati NW, Bernat H (2014). Gambaran indikasi pencabutan gigi dalamperiode gigi bercampur pada siswa SMP Negeri 1 Langowan. Jurnal E- Gigi, 2(2): 1-2.

Notoatmodjo S (2010). Metodologi Penelitian Kesehatan. Jakarta: Rineke Cipta

Sitanaya R (2016). Exodontia (Dasar-Dasar Ilmu Pencabutan Gigi). Edisi ke 1.Yogyakarta: Deepublish.

Warouw BRE, Rattu AJM, Mariani NW (2014). Gambaran pengetahuan dan sikapmasyarakat tentang pencabutan gigi di desa molompor utara kabupaten minahasa tenggara. Jurnal EGigi, 3(1).

Kaurow C, Wowor VNS, Pangemanan DHC (2015). Gambaran status karies peminum alkohol di desa paku weru dua. Jurnal Ilmiah Farmasi, 4(4).

Hardadi M, Maryono J, Mariati NW (2014). Gambaran tindakan pencabutan gigi tetap di 
puskesmas tinumbala kecamatan aertembaga kota bitung tahun 2013. Jurnal E-Gigi, 2(1).

Fachriani Z, Novita CF (2016). Distribusi frekuensi faktor penyebab ekstraksi gigi pasien di rumah sakit umum dr. zainoel abiding banda aceh periode mei-juli 2016. Journal Caninus Dentistry, 1(4).

Fithri Z, Rochim A, Cholid Z (2017). Distribusi pencabutan gigi berdasarkan karakteristik sosiodemografi pada pasien rsgm universitas jember periode januari-desember 2014 (distribution of tooth extraction based on sociodemographic characteristic of dental hospital of university of jember pat). Pustaka Kesehatan, 5(1) 177-184. 